Int. J. Morphol.,

35(1):162-166, 2017.

\title{
The Effect of Gestational Diabetes Mellitus on Sciatic Nerve in Adult Offspring Rats
}

\author{
Efecto de la Diabetes Mellitus Gestacional Sobre el Nervio Ciático en Ratas Adultas
}

\author{
Mehdi Ameri' ${ }^{1}$; Soraya Ghafari²; Zahra Nazari²; Mehdi Mehdizadeh ${ }^{3}$; \\ Majid Asadi Shekari ${ }^{4}$; Mohammadjafar Golalipour ${ }^{2}$
}

AMERI, M.; GHAFARI, S.; NAZARI, Z.; MEHDIZADEH, M.; SHEKARI, M. A. \& GOLALIPOUR, M. The effect of gestational diabetes mellitus on sciatic nerve in adult offspring rats. Int. J. Morphol., 35(1):162-166, 2017.

SUMMARY: Gestational diabetes mellitus (GDM) is one form of diabetes affect approximately $7 \%$ of pregnancies. Diabetic peripheral neuropathy (DPN) is a common complication of diabetes that is associated with loss of nerve fibers, myelin abnormalities and significant decrease in the expression of myelin basic protein (MBP) in peripheral nerves. This study was done to determine the effect of induced diabetes during pregnancy on sciatic nerve in adult rat offspring. In this study, wistar rats' dams were allocated to control and diabetic groups. Diabetic rats were received $40 \mathrm{mg} / \mathrm{kg} /$ body weight of streptozotocin (STZ) on the first day of gestation. Six offspring of each group were randomly selected on 12 weeks postnatal and histopathological changes in their nerve tissue were examined through H\&E staining and transmission electron microscopy. Furthermore, the expression of MBP in sciatic nerve was examined by immunohistochemistry. We found that the myelinated fiber number of sciatic nerve in offspring of diabetic rats was reduced compared to the controls, but this difference was not significant. The average thickness of the myelin sheath of sciatic nerve fibers in the control and GDM was $97.1 \pm 0.1$ and $94.1 \pm 0.2 \mu \mathrm{m}$, respectively that the difference was not statistically significant. The expression of MBP protein in the myelin sheath of both groups was similar. TEM results showed that myelin sheath of diabetic offspring had not any changes compared to control. Atrophy of axons and schwannocytus (Schwann cells) alterations were not observed in diabetic offspring. Induction of diabetes during pregnancy reduced the number of nerve fibers and thickness of the myelin sheath. But it has no effect on MBP expression and schwannocytus morphology.

KEY WORDS: Gestational diabetes mellitus; Sciatic nerve; Myelin basic protein; Schwannocytus (Schwann cell).

\section{INTRODUCTION}

Diabetes mellitus is a chronic disease involving severe insulin dysfunction in conjugation with impairment in glucose homeostasis (Correa et al., 2008). There are three main types of diabetes mellitus: Type 1 DM, Type 2 DM and GDM (Lambrinoudaki et al., 2010). Gestational diabetes mellitus is defined as "impaired glucose tolerance with onset or first recognition during pregnancy. This type of diabetes affects $7 \%$ of pregnancies each year (Landon \& Gabbe, 2011; Lambrinoudaki et al.). Many studies have indicated that offspring of mothers with GDM have significantly higher rates of prenatal mortality and major congenital anomaly (Boloker et al., 2002). Diabetic Embryopathy can causes development of complex diseases during childhood and adulthood. GDM can affect many embryonic organs including heart and neural tube (Loffredo et al., 2001; Persaud, 2007; Vrachnis, 2012; Golalipour et al., 2012).
Diabetic peripheral neuropathies are a group of nerve disorders mostly caused by diabetes (Harati, 2007). DPN associated with progressive degeneration of nerve fibers. The immune damage during the occurrence of diabetes may play a role in the development of DPN. Studies have shown that Loss of nerve fibers, myelin abnormalities and significant decrease in the expression of myelin basic protein occur in DPN (Vinik \& Mehrabyan, 2004; Miranda-Massari, 2011).

Different studies have demonstrated that infants of diabetic mothers have an increased risk for type 2 diabetes as adults (Boloker et al.; Golalipour et al.; Persaud; Loffredo et al.; Vrachnis). Given that, DPN affects about 60 to 70 percent of patients with type 2 diabetes (Young, 1993), the present study was designed to investigate the ultra structural changes occurring in the sciatic nerve in 12 weeks offspring

\footnotetext{
${ }^{1}$ Department of Anatomical Sciences, Golestan University of Medical Sciences, Gorgan, Iran.

${ }^{2}$ Congenital Malformations Research Center, Department of Anatomical Sciences, Golestan University of Medical Sciences, Gorgan, Iran.

${ }^{3}$ Department of Anatomical Sciences, School of Medicine, Iran University of Medical Sciences, Tehran, Iran.

${ }^{4}$ Neuroscience Research Center, Neuropharmacology Institute, Kerman University of Medical Sciences, Kerman, Iran.
} 
of diabetic rats. We also determined the effect of induced diabetes during pregnancy on expression of MBP in sciatic nerve of offspring.

\section{MATERIAL AND METHOD}

Generation of GDM model. All animal experiments were approved by Institutional Animal Care and Use Committee at the Golestan University of medical sciences, Gorgan, Iran. Briefly, female wistar rats aged 12 weeks were separately housed with a male for copulation. Vaginal smear was mentioned daily and mating confirmed by the presence of sperm in a vaginal smear. We used 20 pregnant rats, allocated in control and diabetic groups. Diabetes induced by single intraperitoneal injection of STZ (Sigma) solution (40 mg/kg body weight) in sterile saline solution on day 1 of gestation (Vinik \& Mehrabyan). Control group rats were injected with equivalent volume of normal saline. 72 hour later, blood glucose levels were checked using a glucometer (ACCU-CHEK, Germany). If glucose levels were between $120-250 \mathrm{mg} / \mathrm{dl}$, the rats were selected as GDM. The pregnant rats were allowed to deliver spontaneously. After offspring reached puberty, totally six adult offspring (12 weeks old) from GDM and controls were selected.

Tissue Collection and processing for $\mathrm{H} \& \mathrm{E}$ staining. Offspring rats were anesthetized by intraperitoneal injection of ketamin $(100 \mathrm{mg} / \mathrm{kg})$ and zailazin $(10 \mathrm{mg} / \mathrm{kg})$. For hematoxilin and eosin staining, the bilateral sciatic nerves were isolated and fixed in $10 \%$ formaldehyde. The samples were then dehydrated and embedded in paraffin. Sections (5 $\mu \mathrm{m}$ thick) were stained with hematoxylin and eosin to evaluate the neuronal damage and myelination status. Samples were analyzed under a light Olympus microscope using Olysia Bio software.

Tissue processing for transmission electron microscopy. The sciatic never tissue was isolated and placed in $2.5 \%$ glutaraldehyde at $4{ }^{\circ} \mathrm{C}$ overnight. Tissues were dehydrated with ethanol and was post-fixated with $1 \%$ osmium tetroxide for 1 hour and then embedded in Epon812 resin. The specimens were embedded in Embed-812 resin in BEEM capsules at $60{ }^{\circ} \mathrm{C}$ for 24 hours. By using Leica ultra-cut UCT we obtained semi-thin sections which were stained with toulidine blue and ultra- thin section $(60 \mathrm{~nm})$ were obtained and double stained with uranyl acetate and lead citrate for $10 \mathrm{~min}$. Sections were examined with transmission electron microscopy (Fig. 5).

Immunohistochemistry. Sciatic nerves were fixed with 4 $\%$ paraformaldehyde in PBS (phosphate buffered saline) overnight, dehydrated and embedded in paraffin. Immunocytochemical labeling was performed by monoclonal anti-MBP antibody (Millipore Corporation Billerica, USA) on $5 \mu \mathrm{m}$ thick sciatic nerves sections. Briefly, deparaffinized sections were pre-incubated with citrate buffer and were rinsed with $0.01 \mathrm{~mol} / \mathrm{L}$ PBS three times. Sections were treated with $0.3 \%$ hydrogen peroxide. The sections then incubated with BSA $3 \%$ at $37^{\circ} \mathrm{C}$ for 1 hour to block the non-specific binding. The slides were then incubated with Anti-Myelin Basic Protein Antibody (Millipore MAB382) with 1:100 concentration. After rinse with PBS, the sectioned tissue was incubated with the biotinylated secondary antibody for $10 \mathrm{~min}$. After three times wash with PBS, the section was rinsed with Streptavidin HRP. Immunoreactivity was visualized using DAB for 30 min. Subsequently, the slides were counterstained with Mayer's hematoxylin and mounted with a cover slip. Photomicrographs were taken with a light microscope and were analyzed using Olysia Bio software.

Statistical analysis. Comparisons between groups were analyzed with one-way ANOVA using SPSS16.0 SPSS 16.0 statistical analysis software. Data were presented as mean \pm SEM. In all tests differences were considered significant at values of $\mathrm{P}<0.05$.

\section{RESULTS}

H\&E staining. Histological examination of H\&E stained sciatic nerve showed that there is non-significant difference between the density of the myelinated nerve fibers in control and GDM offspring. Also, the Thickness of the myelin sheaths of control and OGD offspring showed no significant difference (Figs.1-3 and Table I).

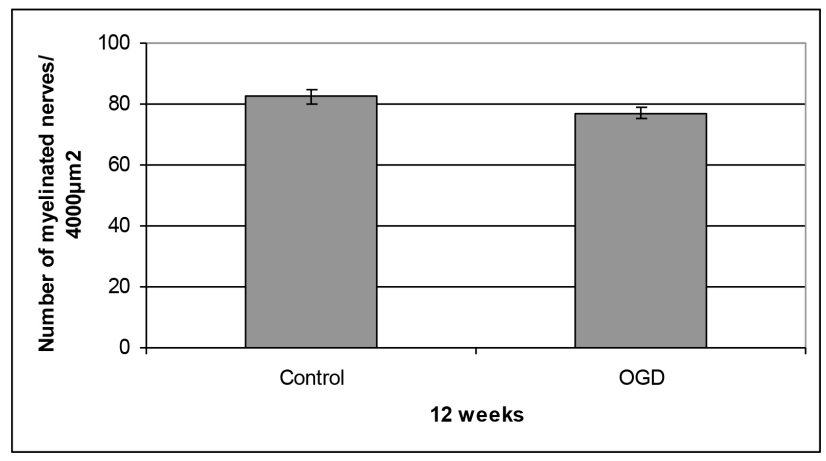

Fig. 1. The number of myelinated axons in $4000 \mu \mathrm{m}^{2}$ area of sciatic nerve of the control and OGD (Offspring of Gestational Diabetes). Results are expressed as Mean \pm SE of the mean, $n=6$ 


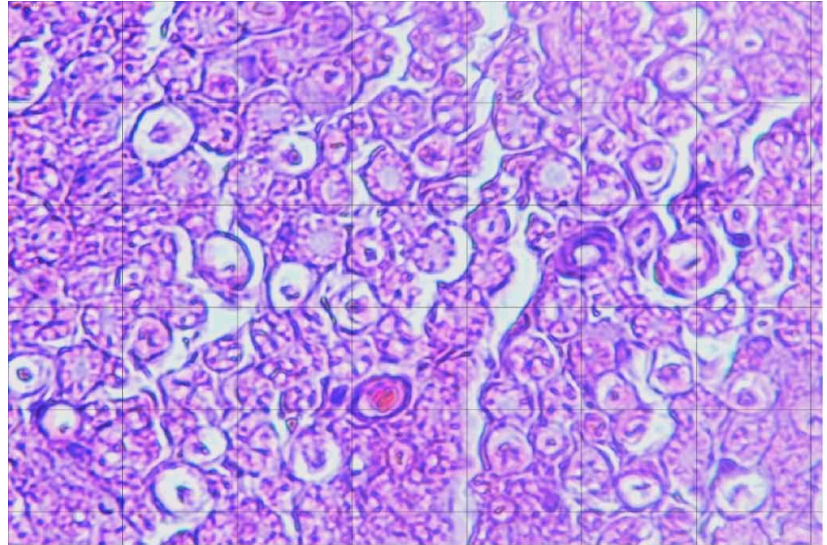

Fig. 2. Histological examination of H\&E stained sciatic nerve of GDM offspring. 1000X (Scale bar: $20 \mu \mathrm{m}$ ).

Table I. Analysis of myelin sheaths thickness and the number of myelinated axons in sciatic nerve of the control and OGD

\begin{tabular}{lccc}
\hline Groups & OGD & Control & P-value \\
\hline Density of the myelinated & $8 / 1 \pm 9 / 76$ & $5 / 2 \pm 5 / 82$ & NS \\
nerve fibers & & & \\
Myelin sheaths thickness & $2 / 0 \pm 94 / 1$ & $1 / 0 \pm 97 / 1$ & NS \\
\hline
\end{tabular}

Results are expressed as Mean \pm SE of the mean, $n=6$ NS= non significant

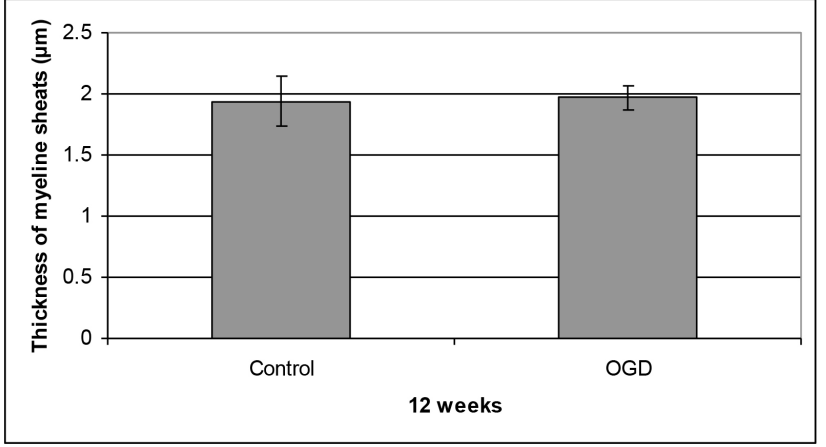

Fig. 3. Compression of myelin sheaths thickness in $4000 \mu \mathrm{m}^{2}$ area of sciatic nerve of the control and OGD (Offspring of Gestational Diabetes). Results are expressed as Mean \pm SEM of the mean, $n=6$.

Immunohistochemistry result. The MBP expression was examined by the immunohistochemistry in the sciatic nerve. Both control and OGD rats showed strong positive staining for MBP in the myelin sheath (Fig. 4).

TEM results. We used transmission electron microscopy to examine the ultrastructure of myelin and schwannocytus (Schwann cell). In the control and OGD rats, the myelinated nerve fibers were similar in size. Furthermore, in both groups
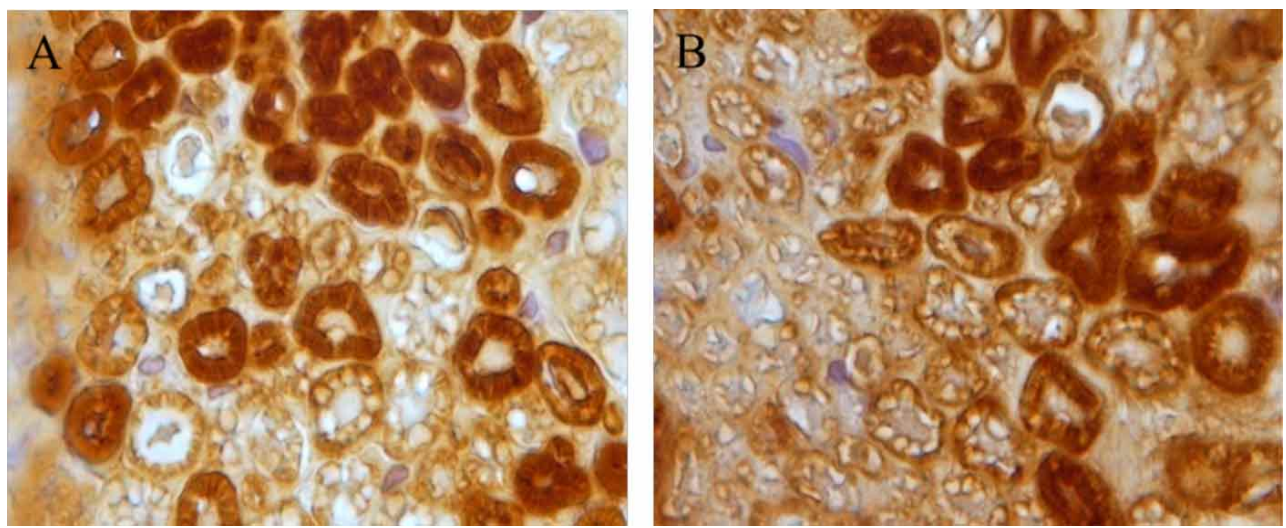

Fig. 4. Immunohistochemical staining of myelin basic protein (MBP) in sciatic nerve. (A) Normal control; (B) offspring of Gestational Diabetes. Magnification $=1000 \mathrm{X}$, scale bars $=20 \mu \mathrm{m}$.
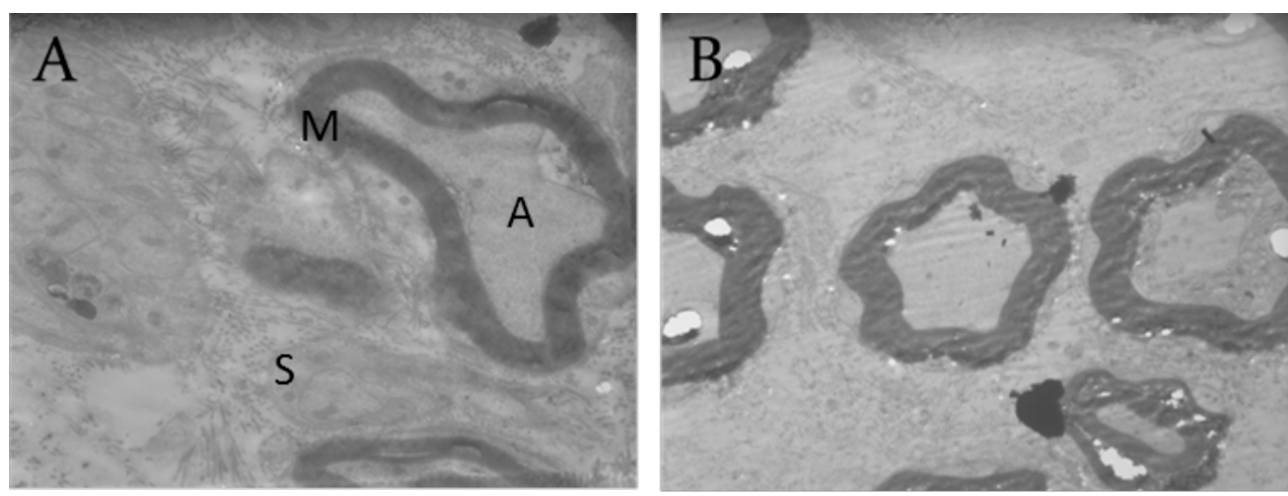

Fig. 5. A transmission electron micrograph of a semi-thin section ( $1 \mu \mathrm{m}$ thick) of the sciatic nerve of the control group (A) and OGD group. No disorganization or demyelination was seen in OGD group compare to controls. Schwannocytus enclosing the axons are seen. A: axon, M: Myelin sheet, S: Schwannocytus. 8000X (Scale bar: $1 \mu \mathrm{m})$. 
myelin appeared dense and uniform with presenting neither axonal shrinkage nor its swelling. Ultrastructure of schwannocytus in control and OGD group showed a well developed Golgi apparatus and normal rough endoplasmic reticulum.

\section{DISCUSSION}

This study was designed to investigate the effect of gestational diabetes mellitus on sciatic nerve ultrastructure in the offspring rats. It has proven that the damage of nerves (DPN) occurs due to high blood glucose levels from diabetes and about half of the people with diabetes develop nerve damage within 10 to 20 years post diagnosis. So, our group wanted to know if maternal DPN causes sciatic nerve damage in the offspring. We also surveyed the expression of MBP protein in normal offspring and OGD. The results of this study demonstrated that GDM does not appear to have an adverse effect on sciatic nerve development in the offspring.

Diabetic peripheral neuropathies are a family of nerve disorders caused by diabetes. It is the main reason for the disability occurring in type 2 diabetes (Harati; Vinik \& Mehrabyan). Metabolic factors, such as high blood glucose, long duration of diabetes, abnormal blood fat levels, and low levels of insulin cause DPN. Functional deficits are the consequence of a loss of nerve fibers, myelin abnormalities, and alternations in connective tissue (Vinik \& Mehrabyan; Comi \& Corbo, 1998).

Resent studies have shown that in diabetic rats the myelin sheath of the myelinated nerve fibers are thin and disorganized (Algaidi, 2011; Kanter, 2008). Shi et al. (2013) study has evaluated the effects of STZ on ultrastructure of sciatic nerve in rats. Their result showed that some nerve fibers in sciatic nerve of diabetic rats appeared demyelinated and axonal atrophy were evident. The average area and the density of myelin nerve fibers was decreased in the DPN group as compared with the control group.

In this study using light microscopy, we have shown that adult offspring rats of GDM exhibit decreased myelinated fiber density, diameter of the myelinated fibers but the difference was not significant. Furthermore, our data from electron microscopy showed that the myelinated nerve fibers were similar in size and shape in OGD and control groups. Also, ultrastructure of schwannocytus in both groups was normal.

MBP is the major constituent protein of the nervous system. This protein binds to the myelin lipids to maintain the myelin structure and promotes the process of myelination. Currently, serum MBP is used as an indicator of the degree of CNS and myelin damage. Studies have proved that MBP decreases under DPN status (Sameni \& Panahi, 2011; Shi). In this study, The MBP expression was examined by the immunohistochemistry in the sciatic nerve. We showed that the expression of this protein is similar in OGD and control offspring.

In conclusion, our data showed that uncontrolled gestational diabetes has no significant effect on structure and ultrastructure of sciatic nerve of adult offspring.

\section{ACKNOWLEDGEMENTS}

This study was supported by Deputy of research Golestan University of Medical Sciences and Gorgan Congenital Malformations research Center, Golestan University of Medical Sciences (Grant number: 306496). The author's thanks from neurosciences research center, Kerman University of Medical Sciences. The data of this article was obtained from Mr. Ameri master's thesis for MSc degree in field of anatomical sciences.

AMERI, M.; GHAFARI, S.; NAZARI, Z.; MEHDIZADEH, M.; SHEKARI, M. A. \& GOLALIPOUR, M. El efecto de la diabetes mellitus gestacional sobre el nervio ciático en ratas adultas. Int. J. Morphol., 35(1):162-166, 2017.

RESUMEN: La diabetes mellitus gestacional (DMG) es una forma de diabetes que afecta aproximadamente al $7 \%$ de los embarazos. La neuropatía periférica diabética (NPD) es una complicación frecuente de la diabetes asociada a la pérdida de fibras nerviosas, anomalías de la mielina y disminución significativa de la expresión de la proteína básica de mielina (PBM) en los nervios periféricos. Este estudio se realizó para determinar el efecto de la diabetes inducida durante el embarazo en el nervio ciático en descendientes de ratas adultas. Las ratas Wistar madres fueron asignadas a los grupos control y diabéticas. Las ratas diabéticas recibieron $40 \mathrm{mg} / \mathrm{kg} /$ peso corporal de estreptozotocina (STZ) el primer día de gestación. Seis descendientes de cada grupo fueron seleccionados al azar en la semana 12 postnatal y los cambios histopatológicos en su tejido nervioso se examinaron a través de tinción H-E y microscopía electrónica de transmisión. Además, la expresión de PBM en el nervio ciático se examinó mediante inmunohistoquímica. Se encontró que el número de fibras mielinizadas de nervio ciático en descendientes de ratas diabéticas se redujo en comparación con los controles, pero esta diferencia no fue significativa. El espesor medio de la vaina de mielina de las fibras nerviosas ciáticas en el control y DMG fue de $97,1 \pm 0,1$ y $94,1 \pm 0,2 \mu \mathrm{m}$, respectivamente, y la diferencia no fue estadísticamente significativa. La expresión de la proteína PBM en la vaina de mielina de ambos grupos fue similar. Los resultados del TEM mostraron que la vaina de mielina 
de la descendencia diabética no tuvo ningún cambio en comparación con el control. La atrofia de los axones y las alteraciones de los schwannocitos (células de Schwann) no se observaron en descendientes diabéticos. La inducción de diabetes durante el embarazo redujo el número de fibras nerviosas y el grosor de la vaina de mielina. Pero no tiene ningún efecto sobre la expresión de PBM y la morfología de las schwannocitos.

PALABRAS CLAVE: Diabetes mellitus gestacional; Nervio ciático; Proteína básica de mielina; Schwannocitos (Célula de Schwann).

\section{REFERENCES}

Algaidi, S. the effect of antioxidants on experimentally induced diabetic peripheral neuropathy in adult male albino rats. J. Am. Sci., 7(12):6717, 2011.

Boloker, J.; Gertz, S. J. \& Simmons, R. A. Gestational diabetes leads to the development of diabetes in adulthood in the rat. Diabetes, 51(5):1499506, 2002.

Comi, G. \& Corbo, M. Metabolic neuropathies.Curr. Opin. Neurol., 11(5):523-9, 1998.

Correa, A.; Gilboa, S. M.; Besser, L. M.; Botto, L. D.; Moore, C. A.; Hobbs, C. A.; Cleves, M. A.; Riehle-Colarusso, T. J.; Waller, D. K. \& Reece, E. A. Diabetes mellitus and birth defects. Am. J. Obstet. Gynecol., 199(3):237.e1-9, 2008.

Golalipour, M. J.; Kafshgiri, S. K. \& Ghafari, S. Gestational diabetes induced neuronal loss in CA1 and CA3 subfields of rat hippocampus in early postnatal life. Folia Morphol. (Warsz.), 71(2):71-7, 2012

Harati, Y. Diabetic neuropathies: unanswered questions. Neurol. Clin., 25(1):303-17, 2007.

Kanter, M. Effects of Nigella sativa and its major constituent, thymoquinone on sciatic nerves in experimental diabetic neuropathy. Neurochem. Res., 33(1):87-96, 2008.

Lambrinoudaki, I.; Vlachou, S. A. \& Creatsas, G. Genetics in gestational diabetes mellitus: association with incidence, severity, pregnancy outcome and response to treatment. Curr. Diabetes Rev., 6(6):393-9, 2010.

Landon, M. B. \& Gabbe, S. G. Gestational diabetes mellitus. Obstet. Gynecol., 118(6):1379-93, 2011.

Loffredo, C. A.; Wilson, P. D. \& Ferencz, C. Maternal diabetes: an independent risk factor for major cardiovascular malformations with increased mortality of affected infants. Teratology, 64(2):98-106, 2001.

Miranda-Massari, J. R.; Gonzalez, M. J.; Jimenez, F. J.; Allende-Vigo, M. Z. \& Duconge, J. Metabolic correction in the management of diabetic peripheral neuropathy: improving clinical results beyond symptom control. Curr. Clin. Pharmacol., 6(4):260-73, 2011.

Persaud, O. D. D. Maternal diabetes and the consequences for her offspring. J. Dev. Disabil., 13(1):101-33, 2007.

Sameni, H. \& Panahi, M. The Effect of Co-administration of 4Methylcatechol and Progesterone on Sciatic Nerve Function and Neurohistological Alterations in Streptozotocin-Induced Diabetic Neuropathy in Rats. Cell J., 13(1):31-8, 2011.

Shi, X.; Chen, Y.; Nadeem, L. \& Xu, G. Beneficial effect of TNF-a inhibition on diabetic peripheral neuropathy. J. Neuroinflammation, 10:69, 2013.

Vinik, A. I. \& Mehrabyan, A. Diabetic neuropathies. Med. Clin. North Am., 88(4):947-99, 2004

Vrachnis, N.; Augoulea, A.; Iliodromiti, Z.; Lambrinoudaki, I.; Sifakis, S. \& Creatsas, G. Previous gestational diabetes mellitus and markers of cardiovascular risk. Int. J. Endocrinol., 2012:458610, 2012.
Young, M. J.; Boulton, A. J.; MacLeod, A. F.; Williams, D. R. \& Sonksen, P. H. A multicentre study of the prevalence of diabetic peripheral neuropathy in the United Kingdom hospital clinic population. Diabetologia, 36(2):150-4, 1993.

Corresponding author:

Dr. Mohammad Jafar Golalipour

Congenital Malformations Research Center

Department of Anatomical Sciences

Golestan University of Medical Sciences

Gorgan

IRAN

Email: mjgolalipour@yahoo.com

Received: 19-11-2016

Accepted: 25-11-2016 